\title{
Soils' role in the formation of groundwater composition and mineralization (on example of the Tatarstan Republic)
}

\author{
Rustam Musin ${ }^{1}$, Eduard Korolev ${ }^{1, *}$, and Ksenia Zotina ${ }^{1}$ \\ ${ }^{1}$ Kazan (Volga region) Federal University, Russia
}

\begin{abstract}
The upper part of the section of the Tatarstan Republic is composed of polyfacial Middle-Upper Permian, Mesozoic, and PlioceneQuaternary sediments. Surface and ground water are characterized here by wide variability of composition and salinity. These variations are determined by a complex of natural and technogenic factors. The most important natural factor is the interaction of precipitation and their derivatives with soils and rocks of the section. Water extracts from the main soil varieties were analyzed on the basis of distilled and thawed snow water in order to evaluate this interaction. The compositions of water extracts are compared with the compositions of the least mineralized spring waters. The components which are supplied in the underground hydrosphere by the soils are determined. It is shown that $50-80 \%$ of the ground water composition, which generate outside the zones of anthropogenic impact, is determined by the interaction of precipitation with the soil cover.
\end{abstract}

\section{Introduction}

The chemical composition and salinity of groundwater are determined by the number of hydrogeochemical processes, controlled by various factors. In areas of sufficient moisture, it usually begins with the interaction of precipitation with soils. Soils as special organomineral formations are distinguished by a complex of fairly easily soluble compounds. Soil scientists at the beginning of the 20th century revealed a significant influence of soils on the composition and salinity of groundwater [1]. Subsequently, the major experts Vernadsky V.I., Posokhov E.V., Shvartsev S.L. and others pointed out that soil is one of the factors determining the composition of the groundwater of upper hydrological aquifers [24]. Despite this, in many cases, hydrogeochemists do not consider the influence of a soil.

The purpose of this article is to further confirm the relationship of the composition of groundwater with the land cover using the example of the Tatarstan Republic. The Tatarstan Republic is characterized by significant variability of soils and geological and hydrogeological conditions of landscapes.

\footnotetext{
*Corresponding author: edik.korolev@gmail.com
} 


\section{Objects and methods of research}

The objects of the study were the features of the composition of groundwater (the waters of the first aquifer from the surface) and the soil layer in certain regions of the Tatarstan Republic. The main research methods are the method of water extracts and a comprehensive analysis of hydrogeochemical information.

The Tatarstan Republic is located in the eastern part of the East European platform and within the Volga-Ural artesian basin. Its area is 68 thousand $\mathrm{km}^{2}$. The Republic has a powerful industrial potential, intensive development of oil fields and active agro-industrial complex. The forest area - 17\%, agricultural area - 65\% [5].

The substrate of the upper aquifers within the Tatarstan Republic is composed of complexes of polygenic Permian, marine Jurassic-Cretaceous and alluvial PlioceneQuaternary deposits. Permian formations are characterized by the maximum extent area. They have a sulphate-carbonate-terrigenous composition and a total thickness up to $350 \mathrm{~m}$, with a thickness of individual layers of 0.1-20 m. Mesozoic clay deposits with thickness up to $300 \mathrm{~m}$ are developed only in the south-western part of the Republic. Pliocene quaternary sandy-argillaceous deposits are developed in river valleys which have the width $10-15 \mathrm{~km}$ and the depth of the channels cut by rivers is $150-220 \mathrm{~m} \mathrm{[6].}$

The thickness of the fresh groundwater zone in the Tatarstan Republic reaches 200-300 $\mathrm{m}$. The groundwater recharge is atmospheric precipitation in watershed areas, and discharge takes place in river valleys. The depth of groundwater aquifers varies from 1-2 to $40 \mathrm{~m}$. Mean annual precipitation in Tatarstan is $\sim 500 \mathrm{~mm} /$ year, of which the share of effective precipitation is $12-20 \%$. The total resource potential of fresh groundwater is 5.46 million $\mathrm{m}^{3} /$ day, and the amount of explored drinking quality water reserves is 2.29 million $\mathrm{m}^{3} /$ day [5].

In The Tatarstan Republic there are more than 10 types of soils. Gray forest and sodpodzolic soils predominate in the northern part of the Tatarstan Republic (Predkamsky region). In the western (Predvolzhsky region) and southern (Zakamsky region) parts there are gray forest, as well as leached and typical chernozems [7]. The thickness of the soil cover varies from $0.2-0.3$ to $0.8-1.0 \mathrm{~m}$ (maximum values are in the field of chernozem development), the prevailing values are $0.4 \mathrm{~m}$.

The composition and salinity of underground water of the upper part of the section vary widely. Their salinity naturally increases from $0.15-0.2$ to $0.6-1.0 \mathrm{~g} / \mathrm{L}(2-2.5 \mathrm{~g} / \mathrm{L})$ downwards the section and toward discharge zones. Their composition varies from $\mathrm{HCO}_{3} / \mathrm{Ca}$ and $\mathrm{HCO}_{3} / \mathrm{Mg}-\mathrm{Ca}$ to $\mathrm{HCO}_{3} / \mathrm{Na}$ and $\mathrm{SO}_{4} / \mathrm{Mg}$-Ca. It is explained by the different interaction time between water and carbonate-terrigenous (sometimes sulphate-carbonateterrigenous) water-bearing mineral matrix.

The most important hydrogeochemical processes are carbon dioxide leaching of carbonate-terrigenous rocks, leaching and dissolution of gypsum, hydrolysis of terrigenous rocks, sorption and ion exchange, and others. These processes with different intensity occur in water-bearing rocks of different composition and age. Water salinity usually does not exceed $1.0 \mathrm{~g} / \mathrm{L}$, and the hardness is $7 \mathrm{mM} / \mathrm{L}$, when there are no or only a few gypsum, while the quality of groundwater is potable. Sometimes elevated concentrations of iron and manganese are observed (up to 1.0 and $0.8 \mathrm{mg} / \mathrm{L}$, respectively).

The anthropogenic factor plays a significant role in the formation of the composition of underground water in the territory of settlements, within large industrial zones, in the areas of surface landfills for disposal of various wastes, as well as in areas of large oil fields that have been developed for more than 50 years. Salinity of ground water reaches 5-12 g/L here, and hardness is $80-135 \mathrm{mM} / \mathrm{L}[8,9]$.

46 soil samples were leached by water to determine the influence of soil type on the composition of groundwater. These samples characterize the all layers of soil profile. The process of extracts preparation is as follows: 100 grams of crushed rock is poured into 1 
liter of water. After one day the extract is filtered and analyzed. Authors used distilled and melted snow water to prepare the extracts. Melt water has a bicarbonate sodium-calcium composition:

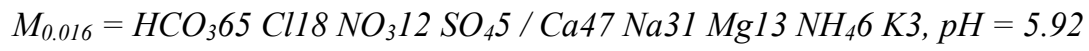

The $\mathrm{pH}$, electrical conductivity, turbidity, colour, $\mathrm{COD}_{\mathrm{KMnO} 4}$, contents of $\mathrm{HCO}_{3}{ }^{-}, \mathrm{SO}_{4}{ }^{2-}$, $\mathrm{Cl}^{-}, \mathrm{NO}_{3}{ }^{-}, \mathrm{NO}_{2}^{-}, \mathrm{F}^{-}, \mathrm{PO}_{4}{ }^{3-}, \mathrm{Ca}^{2+}, \mathrm{Mg}^{2+}, \mathrm{Na}^{+}, \mathrm{K}^{+}, \mathrm{NH}_{4}{ }^{+}, \mathrm{Li}^{+}$, as well as the concentrations of $\mathrm{Fe}, \mathrm{Mn}, \mathrm{Pb}, \mathrm{Ni}, \mathrm{Cd}, \mathrm{Cu}, \mathrm{Co}, \mathrm{Cr}, \mathrm{Zn}$ have been analysed in the leachates (extracts). The ionic composition was analyzed using ion chromatographs Dionex ICS-1600, and metals were detected on the Atomic-Absorption spectrometer ContrAA700. The composition of the water extracts was compared with the composition of the least mineralized groundwaters (127-250 mg/L, 100 samples) sampled from the springs. Such springs are located outside the zones of intensive anthropogenic impact, in the upper part of the watershed slopes. They are descending and this is a subaerial discharge of the waters of the first aquifer. The short interaction of precipitation with soils and rocks of different types of rocks determines their composition (Fig. 1).

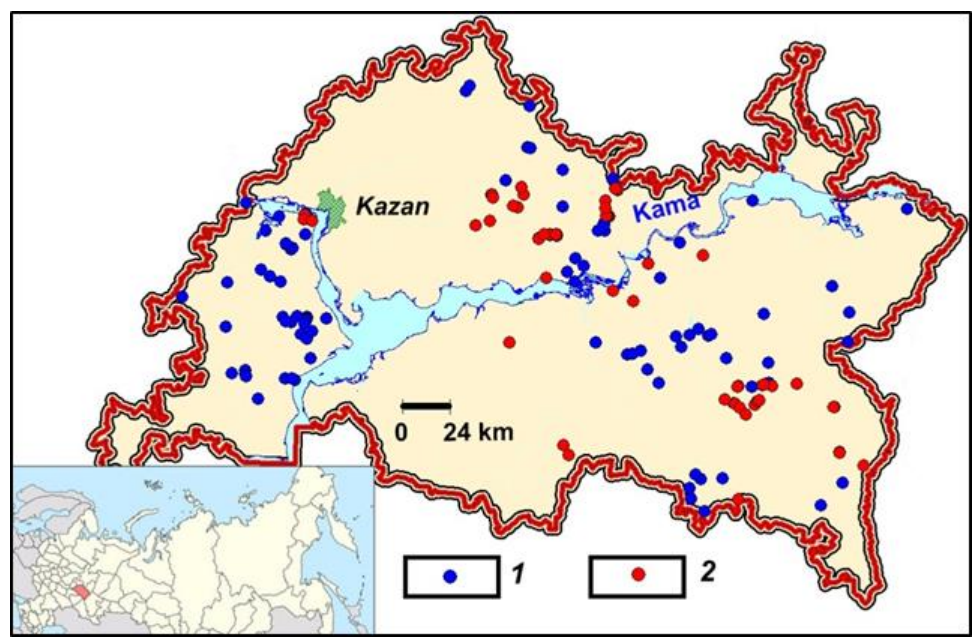

Fig. 1. Location of the objects studied within the Tatarstan Republic:

1 - springs with water mineralization less than $250 \mathrm{mg} / \mathrm{L} ; 2$ - places where soil samples are taken.

\section{Results and discussions}

The salinity and composition of water extracts of soil samples based on different types of water have similar values (Table 1). Therefore, the authors further consider them together.

Table 1. Features of the composition of soil water extracts based on distilled and melted snow water.

\begin{tabular}{|c|c|c|c|c|c|}
\hline Water & Salinity, mg/L & $\begin{array}{c}\text { Hardness, } \\
\mathrm{mM} / \mathrm{L}\end{array}$ & $\mathrm{pH}$ & $\begin{array}{l}\text { CODMn, } \\
\mathrm{mgO} / \mathrm{L}\end{array}$ & $\begin{array}{l}\text { Water } \\
\text { type }\end{array}$ \\
\hline $\begin{array}{l}\text { Distilled } \\
\text { water }\end{array}$ & $\frac{40-279}{174 \pm 80}$ & $\frac{0.31-2.11}{1.16 \pm 0.46}$ & $\frac{7.40-8.20}{7.95 \pm 0.25}$ & $\frac{6.20-10.50}{9.43 \pm 1.10}$ & $\mathrm{HCO}_{3} / \mathrm{Ca}$ \\
\hline $\begin{array}{c}\text { Melted } \\
\text { snow water }\end{array}$ & $\frac{34-294}{175 \pm 70}$ & $\frac{0.34-3.48}{1.38 \pm 0.79}$ & $\frac{6.20-8.10}{7.50 \pm 0.49}$ & $\frac{1.0-11.0}{7.96 \pm 2.56}$ & $\mathrm{HCO}_{3} / \mathrm{Ca}$ \\
\hline
\end{tabular}

Note. 12 soil samples are compared; in the numerator - limit values (minimum-maximum), in the denominator - mean values $\underline{ \pm}$ standard deviation. 
Water extracts from the soils of the Zakamsky (southern) region have higher salinity and permanganate index than extracts from the Predkamsky (northern) region (Table 2). In the first region chernozems are mostly, and in the second - sod-podzolic soils.

Table 2. Comparison of water extracts of the soils of the Predkamsky and Zakamsky regions.

\begin{tabular}{|c|c|c|c|c|c|c|}
\hline Region & $\begin{array}{c}\text { Number } \\
\text { of samples }\end{array}$ & $\begin{array}{c}\text { Salinity, } \\
\mathrm{mg} / \mathrm{L}\end{array}$ & $\begin{array}{c}\text { Hardness, } \\
\mathrm{mM} / \mathrm{L}\end{array}$ & $\mathrm{pH}$ & $\begin{array}{l}\mathrm{COD}_{\mathrm{Mn}}, \\
\mathrm{mgO} / \mathrm{L}\end{array}$ & $\begin{array}{l}\text { Water } \\
\text { type }\end{array}$ \\
\hline \multirow[t]{2}{*}{ Predkamsky } & \multirow[t]{2}{*}{11} & $37-284$ & $0.27-2.41$ & $6.60-7.50$ & $1.0-11.0$ & \multirow[t]{2}{*}{$\mathrm{HCO}_{3} / \mathrm{Ca}$} \\
\hline & & $119 \pm 76$ & $1.15 \pm 0.76$ & $7.07 \pm 0.30$ & $8.03 \pm 2.49$ & \\
\hline \multirow[t]{2}{*}{ Zakamsky } & \multirow[t]{2}{*}{29} & $34-294$ & $\underline{0.31-3.48}$ & 5.6-9.05 & $10.6-17.0$ & \multirow[t]{2}{*}{$\mathrm{HCO}_{3} / \mathrm{Ca}$} \\
\hline & & $168 \pm 74$ & $1.27 \pm 0.67$ & $7.53 \pm 0.80$ & $13.5 \pm 1.93$ & \\
\hline
\end{tabular}

Note. In the numerator - limit values, in the denominator - mean values \pm standard deviation.

In the Zakamsky and Predkamsky regions, the maximum values of salinity, the amounts of organic substances and nitrogen compounds $\mathrm{NH}_{4}{ }^{+}$and $\mathrm{NO}_{2}{ }^{-}$are observed in meadow and forest areas. Sandy soils of river valleys have minimal values. Soils in agricultural fields have intermediate values.

Low-mineralized spring waters have higher salinity and hardness than water extracts of the soil (Table 3). At the same time, the soils extracts are enriched with organic matter and nitrogen compounds (Table 4), while the concentrations of most of the other components are almost similar.

Table 3. Comparison of the composition of water extracts and spring water.

\begin{tabular}{|c|c|c|c|c|c|}
\hline Region & Water type & $\begin{array}{c}\text { Number } \\
\text { of samples }\end{array}$ & $\begin{array}{c}\text { Salinity, } \\
\mathrm{mg} / \mathrm{L}\end{array}$ & $\begin{array}{c}\text { Hardness, } \\
\mathrm{mM} / \mathrm{L}\end{array}$ & $\begin{array}{c}\mathrm{HCO}_{3}^{-}, \\
\mathrm{mg} / \mathrm{L}\end{array}$ \\
\hline \multirow{2}{*}{ Predvolzhsky } & Spring water & 47 & $\frac{155-249}{219+28}$ & $\frac{2.76-5.36}{4.16 \pm 0.60}$ & $\frac{134-317}{238+47}$ \\
\hline & Water extracts & 6 & $\frac{124-229}{179 \pm 48}$ & $\frac{0.8-2.40}{1.45 \pm 0.65}$ & $\frac{37-146}{76 \pm 44}$ \\
\hline \multirow[t]{2}{*}{ Predkamsky } & Spring water & 17 & $\frac{127-250}{227 \pm 30}$ & $\frac{1.94-7.85}{4.25 \pm 1.2}$ & $\frac{92-281}{243 \pm 48}$ \\
\hline & Water extracts & 11 & $\begin{array}{c}37-284 \\
119 \pm 76\end{array}$ & $\begin{array}{l}0.27-2.41 \\
1.15 \pm 0.76\end{array}$ & $\frac{15-120}{71 \pm 41}$ \\
\hline \multirow[t]{2}{*}{ Zakamsky } & Spring water & 36 & $\frac{180-249}{222 \pm 21}$ & $\frac{3.1-4.75}{4.1 \pm 0.44}$ & $\frac{134-281}{199 \pm 39}$ \\
\hline & Water extracts & 29 & $\frac{34-294}{168 \pm 74}$ & $\frac{0.31-3.48}{1.27 \pm 0.67}$ & $\frac{12-214}{116 \pm 56}$ \\
\hline
\end{tabular}

Note. In the numerator - limit values, in the denominator - mean values \pm standard deviation.

Table 4. Permanganate index and concentrations of nitrogen compounds in water extracts and springs.

\begin{tabular}{|c|c|c|c|c|c|}
\hline Region & Water type & $\begin{array}{c}\text { Number } \\
\text { of samples }\end{array}$ & $\mathrm{NO}_{2}^{-}, \mathrm{mg} / \mathrm{L}$ & $\mathrm{NH}_{4}^{-}, \mathrm{mg} / \mathrm{L}$ & $\begin{array}{l}\text { CODMn, } \\
\mathrm{mgO} / \mathrm{L}\end{array}$ \\
\hline \multirow[t]{2}{*}{ Predvolzhsky } & Spring water & 47 & $\frac{0.0-1.9}{0.08 \pm 0.38}$ & $\frac{0.0-0.23}{0.09 \pm 0.08}$ & $\frac{0.3-5.2}{2.4 \pm 1.1}$ \\
\hline & Water extracts & 6 & $\frac{0.1-1.02}{0.55 \pm 0.37}$ & $\frac{0.0-1.58}{0.66 \pm 0.63}$ & $\frac{5.3-10.9}{7.9 \pm 3.2}$ \\
\hline \multirow[t]{2}{*}{ Predkamsky } & Spring water & 17 & $\frac{0.0-0.13}{0.03 \pm 0.03}$ & $\frac{0.0-0.46}{0.15 \pm 0.14}$ & not determined \\
\hline & Water extracts & 11 & $\frac{0.0-0.49}{0.06 \pm 0.15}$ & $\begin{array}{c}0.0-4.6 \\
0.45 \pm 1.38\end{array}$ & $\frac{1.0-11.0}{8.03 \pm 2.49}$ \\
\hline \multirow[t]{3}{*}{ Zakamsky } & Spring water & 36 & $0.0-1.58$ & $0.0-0.2$ & $0.0-8.5$ \\
\hline & & & $0.08 \pm 0.31$ & $0.03 \pm 0.04$ & $2.78 \pm 2.22$ \\
\hline & Water extracts & 29 & $\frac{0.0-3.97}{0.58 \pm 1.06}$ & $\frac{0.0-15.2}{2.25 \pm 4.28}$ & $\frac{10.6-17.0}{13.5 \pm 1.93}$ \\
\hline
\end{tabular}


Note. In the numerator - limit values, in the denominator - mean values \pm standard deviation.

The salinity and hardness of ground water is higher than these parameters of water extracts. This is due to their formation under conditions of high carbon dioxide activity. While the composition of the extracts in the laboratory was formed at a $\mathrm{CO}_{2}$ content 300 ppm, the composition of the groundwater within the Tatarstan Republic is formed at $\mathrm{CO}_{2}$ concentrations at 800-120000 ppm (depth of the soil and subsoil layers). The authors obtained this data during the gas survey with the Ecoprobe-5 analyzer in many regions of the Tatarstan Republic. Therefore, groundwater in the aeration zone and in the saturation zone is characterized by both higher hydrocarbon content and higher carbon dioxide aggressiveness and leaching capacity. Fe (up to $3.3 \mathrm{mg} / \mathrm{L}$ ); $\mathrm{Mn}$ (up to $0,5 \mathrm{mg} / \mathrm{L}$ ) often actively moving from soil in distilled water and melted snow water (Table 5).

Table 5. Concentrations of $\mathrm{Fe}$ and $\mathrm{Mn}$ in water extracts and spring water samples.

\begin{tabular}{|c|c|c|c|c|}
\hline Region & Water type & $\begin{array}{c}\text { Number of } \\
\text { samples }\end{array}$ & $\mathrm{Fe}, \mathrm{mg} / \mathrm{L}$ & $\mathrm{Mn}, \mathrm{mg} / \mathrm{L}$ \\
\hline \multirow[t]{3}{*}{ Predkamsky } & Spring water & 17 & $\frac{0.010-0.350}{0.080 \pm 0.081}$ & $\frac{0.00-0.130}{0.041 \pm 0.040}$ \\
\hline & Water extracts & 8 & $0.00-3.309$ & $0.004-0.516$ \\
\hline & & & $0.85 \pm 1.21$ & $0.091 \pm 0.184$ \\
\hline \multirow[t]{2}{*}{ Zakamsky } & Spring water & 36 & $\frac{0.016-0.691}{0.076 \pm 0.138}$ & $\frac{0.005-0.084}{0.035 \pm 0.018}$ \\
\hline & Water extracts & 9 & $\frac{0.07-2.9}{1.14 \pm 1.12}$ & $\frac{0.005-0.538}{0.15 \pm 0.192}$ \\
\hline
\end{tabular}

Note. In the numerator - limit values, in the denominator - mean values \pm standard deviation.

\section{Conclusions}

1. The interaction of precipitation with soil cover determines the composition and salinity of groundwater of the upper aquifer within the Tatarstan Republic. This is explained by the fact that water extracts of soil samples have a predominant salinity not less than $100 \mathrm{mg} / \mathrm{L}$, and the minimum salinity of spring water is usually $150-200 \mathrm{mg} / \mathrm{L}$.

2. Soil water extracts are less mineralized than spring waters (due to $\mathrm{HCO}_{3}{ }^{-}, \mathrm{Ca}^{2+}$, $\left.\mathrm{Mg}^{2+}\right)$. This is due to the fact that the composition of spring water is formed longer, and also the fact that under natural conditions the formation of groundwater composition occurs under a higher partial pressure of carbon dioxide, which determines the increased carbon dioxide aggressiveness of water.

3. $\mathrm{NO}_{2}^{-}, \mathrm{NH}_{4}^{+}$, organic matter and, to a lesser extent, Fe and $\mathrm{Mn}$ are delivered to the groundwaters as soils leachates.

4. Soils within forests and meadow areas are characterized by the maximum mineralizing role. The soils of river valleys have a minimal mineralizing role. The soils of the cultivated fields are characterized by an average mineralizing role.

This study was performed in the context of the Russian Government Program of Competitive Growth of Kazan Federal University.

\section{References}

1. A. I. Perelman, Geochemistry of natural water (Nauka, Moscow, 1982)

2. V. I. Vernadsky, History of Natural Waters (Nauka, Moscow; 2003) 
3. E. V. Posohov, Formirovaniye himicheskogo sostava podzemnih vod (Leningrad, Gidrometeoizdat, 1969)

4. S. L. Shvartsev, Hydrogeochemistry of the hypergenesis zone (Moscow, Nedra, 1978)

5. State report on the state of natural resources and environmental protection of the Republic of Tatarstan in 2015 (Kazan, 2016)

6. B. V. Burov, Geology of Tatarstan: Stratigraphy and tectonics (GEOS Publising house, Moscow, Russia, 2003)

7. M. K. Latipov, Nomenclature and taxonomy of the main soil types of the Tatarstan Republic (KFU, Kazan, 2008)

8. R. K. Musin, E. A. Korolev, K. E. Zotina, In 17th International Multidisciplinary Scientific GeoConference SGEM, Variations and conditions of the composition natural waters in the Central European Russia (on example of the Tatarstan Republic), 17, 777-784 (2017)

9. R. Kh. Musin, N. A. Kurlyanov, Z. G. Kalkamanova, T. V. Korotchenko, IOP Conf. Series: Earth and Environmental Science, Environmental state and buffering properties of underground hydrosphere in waste landfill site of the largest petrochemical companies in Europe, 33 (2016) 